\title{
Neurological disorder associated with pestivirus infection in sheep in Rio Grande do Sul, Brazil
}

\author{
Distúrbio neurológico em ovino associado com infecção por pestivírus no \\ Rio Grande do Sul, Brasil
}

\author{
Caroline Argenta Pescador ${ }^{1}$ Luis Gustavo Corbellini ${ }^{2}$ David Driemeier $^{3}$ \\ Ricardo Kalil Gonçalves ${ }^{4}$ Cláudio Estêvão Farias Cruz ${ }^{2}$
}

\section{- CASE REPORT -}

\section{ABSTRACT}

A two-month-old lamb showing signs of severe neurological disease characterized by muscular tremors, hypermetria, and motor incoordination was submitted to the Veterinary Pathology Laboratory - Universidade Federal do Rio Grande do Sul, Brazil. At necropsy, the major findings were a marked reduction of the size of the cerebellum and bilateral dilatation of the lateral ventricles. Microscopically, areas of cellular disorganization in the cerebellar cortex, reduction of the granular layer of cerebellum associated with decreased density of cells, and the presence of large cytoplasmic vacuoles in the molecular layer were observed. Neurons of the gray matter of the brain and macrophages of the mesenteric lymph nodes stained positively by the immunohistochemistry test using the monoclonal antibody 15C5 against Bovine Viral Diarrhea Virus. Taken together, those results are consistent with a pestivirus infection, or Border Disease Virus (BDV) or BVDV.

Key words: pestivirus, Border Disease, sheep, Brazil.

\section{RESUMO}

Um cordeiro de dois meses de idade apresentando sinais severos de doença neurológica foi enviado ao Laboratório de Patologia Veterinária - Universidade Federal do Rio Grande do Sul. Os sinais clínicos consistiam de tremores musculares, hipermetria e incoordenação motora. Os principais achados de necropsia foram uma pronunciada redução do tamanho do cerebelo e dilatação bilateral dos ventrículos laterais. As alterações microscópicas consistiram de áreas de desorganização celular no córtex cerebelar, redução da camada granular do cerebelo associada com diminuição da densidade de células e a presença de grandes vacúolos citoplasmáticos na camada molecular. Cortes histológicos foram submetidos à imunoistoquímica, utilizando o anticorpo monoclonal 15C5 contra o vírus da Diarréia Viral Bovina (BVDV). Reação positiva foi detectada difusamente nos neurônios da substância cinzenta e em macrófagos dos linfonodos mesentéricos. Os achados clínicos, histopatológicos e imunoistoquímicos sugerem que este cordeiro tenha sido infectado por um pestivírus, provavelmente Border Disease Vírus (BDV) ou BVDV.

Palavras-chave: pestivirus, Doença de Border, ovino, Brasil.

The pestivirus genus of the Flaviviridae includes Bovine Viral Diarrhea Virus (BVDV), Border Disease Virus of sheep (BDV) and Classical Swine Fever Virus (CSFV). All pestiviruses are structurally and antigenically closely related and cross infection between species may occur (TERPSTRA \& WENSVOORT 1988, CARLLSON 1991, PATON et al., 1995, NETTLETON et al., 1998). BDV is associated with congenital disease in sheep however not as commonly as is BVDV in cattle. It is found worldwide. The clinical disease is usually manifested by barren ewes, abortion, and stillbirths. Affected lambs may have low birth weight, abnormalities of conformation and fleece, tremors, ataxia and

${ }^{1}$ Médico Veterinário, aluna de mestrado, Departamento de Patologia Veterinária, Universidade Federal do Rio Grande do Sul (UFRGS), Porto Alegre, RS, Brasil.

${ }^{2}$ Médico Veterinário, aluno de doutorado, Departamento de Patologia Veterinária, UFRGS

${ }^{3}$ Médico Veterinário, Professor Adjunto, Departamento de Patologia Veterinária, UFRGS, CP 15094, 91540-000, Porto Alegre, RS. Email: davetpat@vortex.ufrgs.br. Autor para correspondência.

${ }^{4}$ Médico Veterinário autônomo, Bagé, RS, Brasil. E-mail: rikag@alternet.com.br 
occasionally enteric dysfunction (BARLOW et al., 1983, NETTLETON \& ENTRICAN 1995, MONIES \& SIMPSON 1997, RADOSTITS et al., 2000).

Spread of BDV within a flock may take years in sheep reared on grass, but is highly favored by intensive systems of management, which allow close contact among animals. The infection of fetuses can result in the birth of persistently infected lambs, which have been considered the most important source of infection. Several diagnostic methods for pestiviruses have been reported (NETTLETON \& ENTRICAN 1995, NETTLETON et al., 1998). Immunohistochemical analysis with the use of monoclonal antibodies (Mabs) against BVDV may be used to detect pestiviruses in affected ovine fetuses and lambs (THÜR et al., 1997, RADOSTITS et al., 2000). Gross findings associated with border disease include abnormal wool coat, reduction in the size of the brain and spinal cord, arthrogryposis, hydranencephaly, porencephaly, and cerebellar dysplasia. Histologically, hypomyelinogenesis, nodular periarteritis, necrosis and inflammation of the germinal layers of the central nervous system have been described (JUBB \& HUXTABLE 1993, THOMSON \& HARKNESS 1994, RADOSTITS et al., 2000).
Even though BVDV infection has been demonstrated as a disseminated condition in Brazilian cattle (BOTTON et al., 1998, CANAL et al., 1998, FLORES et al., 2000), pestiviral infection of sheep has not yet been reported in Brazil.

The case reported here occurred in July 1998 in a flock of 300 Texel sheep that were maintained on grass. The farm is located in the county of Bagé, state of Rio Grande do Sul, Brazil. Both the ovine and bovine herds from this farm had occasionally been managed in the same paddocks. Among the sheep, 150 were twomonth-old lambs, of which only one lamb, despite being twinborn, had showed clinical signs since its birth. The apparently healthy twin lamb was not available for further studies. The dam of the twins had been imported from Germany three months before parturition. The affected 50-days-old lamb was brought to the Pathology Laboratory - UFRGS alive, and presented muscular tremors, hypermetria, and general incoordination. Because of the lack of response to antimicrobial therapy (eight days) and continuous deteriorating conditions, the lamb was euthanized. At necropsy, the principal findings were a marked reduction of the size of the cerebellum (Figure 1) and bilateral dilatation of the lateral ventricles. Tissue samples from several organs,

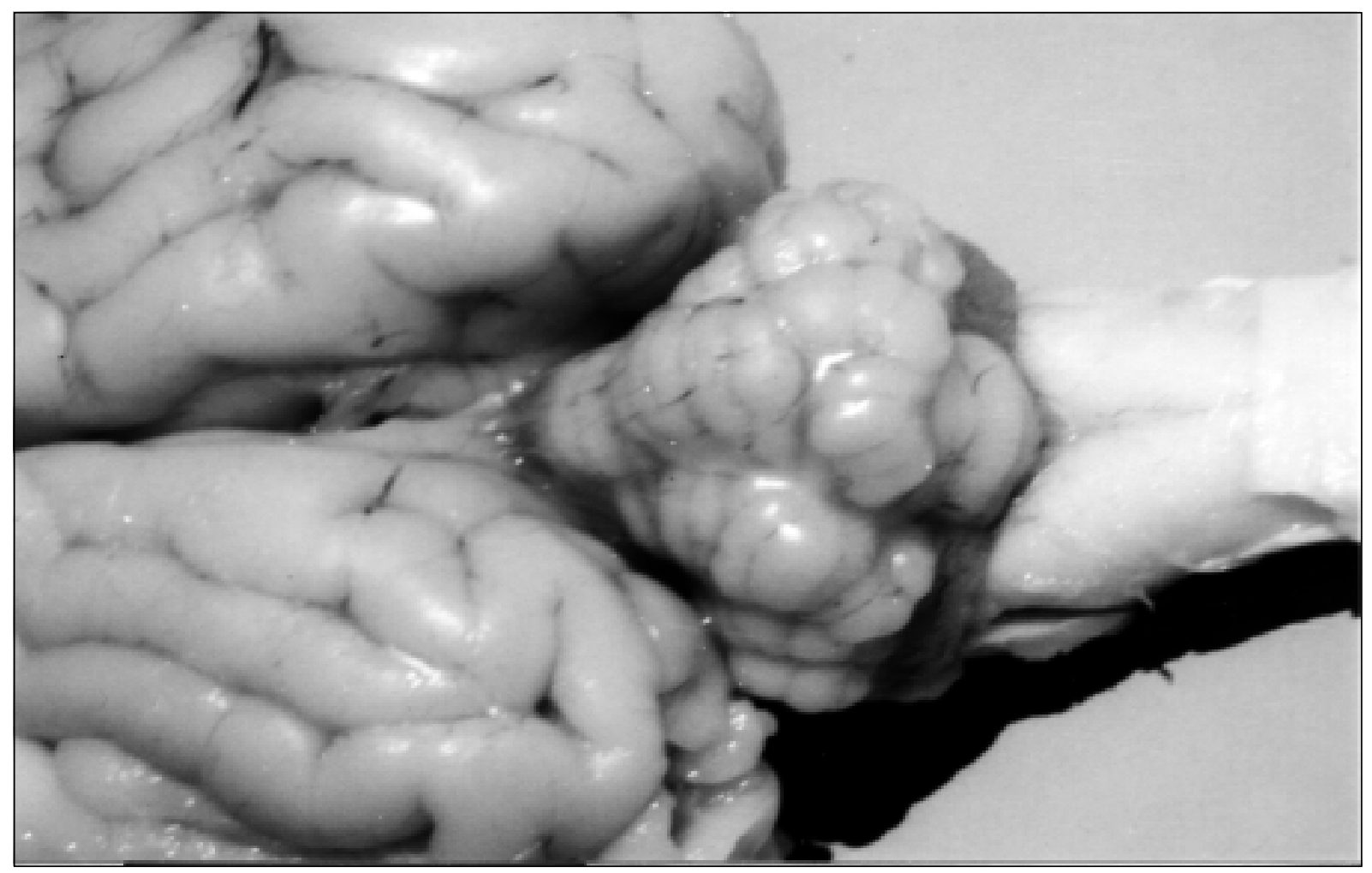

Figure 1 - Reduced size of the cerebellum (dorsal encephalic view). 
including the central nervous system, were processed by standard histologic methods and stained by haematoxylin and eosin. Microscopically, areas of cellular disorganization in the cerebellar cortex, reduction of the granular layer of cerebellum associated with decreased cell density, and presence of large cytoplasmic vacuoles in the molecular layer were observed. Immunohistochemistry was performed on formalin-fixed, paraffin-embedded sections of cerebellum, brain, and lymph nodes. The MAb 15C5 against BVDV (at a dilution of 1:1000) was applied using the avidin-biotin method. Diaminobenzidine served as chromogen. Positive controls stained concurrently with each batch consisted of tissues from cattle that died from acute BVDV type 2 (BVDV-2) infection (FLORES et al., 2000). Clearly positive reactions were detected consistently in the neurons from the gray matter (Figure 2), and macrophages from mesenteric lymph nodes. BVD - Seroneutralization test was performed in the Virology Laboratory - UFRGS, but only on samples from eleven animals of this flock, and resulted negative.

The clinical and pathological findings from this study are consistent with previous descriptions of pestiviral infection (NETTLETON \& ENTRICAN
1995, NETTLETON et al., 1998, RADOSTITS et al., 1994). The correlation previously observed between the presentation of neurological dysfunction in neonatal lambs and BDV infection (THÜR et al., 1998) is an additional argument that supports a BD diagnosis in this case. According to their reactivity with MAbs against glycoprotein E, ruminant pestiviruses have been described to display an antigenic relationship of about 60\% (TIJSSEN et al., 1996, RIJN et al., 1997). Likewise, BVD strains have already been classified, also in base of Mabs reactivity, into BVDV type $1 \mathrm{~b}$ and type 2 groups (TIJSSEN et al., 1996, RIJN et al., 1997). Therefore, we believe that the immunostaining pattern using Mab 15C5 observed in this study could be associated with either BVDV infection or with infection by a BDV strain that extensively shares common antigens with BVDV. The true source of this infection is not known, however, a link between the imported sheep and the condition described here could be suggested. Additional data on this case is not available because much time has elapsed since it occurred. However, from the history and diagnostic findings on this case, the etiologic role of BDV is a plausible conclusion, thus making this case the first well-documented evidence of the occurrence of this condition in Brazil.

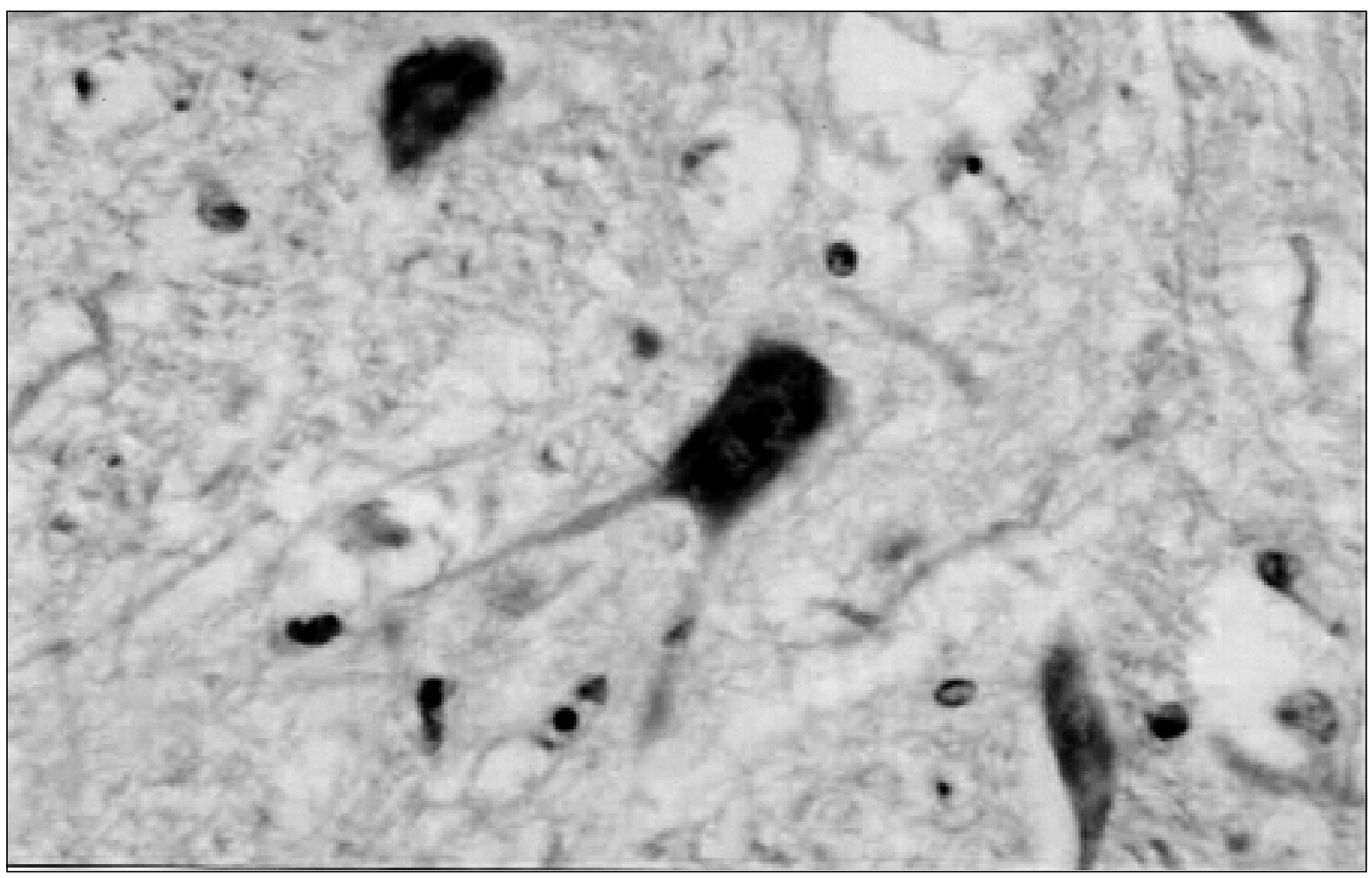

Figure 2 - Immunohistochemical analysis performed on brain section of a lamb using monoclonal antibody $15 \mathrm{C} 5$ against BVDV. Note positive staining of the neurons. 
The Financial support was provided in part by a grant from the FAPERGS, Brazil (N 01/0679.4). The authors are grateful to Dr. Eduardo Furtado Flores (DMVP/CCR/UFSM) and Fernando A. Osorio (University of Nebraska-Lincoln, USA) for technical assistance.

\section{REFERENCES}

BARLOW, R.M.; GARDINER, A.C.; NETTLETON, P.F. The pathology of a spontaneous and experimental mucosal diseaselike syndrome in sheep recovered from clinical border disease. Journal of Comparative Pathology, v.93, p.451-461, 1983.

BOTTON, S.A. et al. Antigenic characterization of Brazilian isolates of bovine viral diarrhea virus (BVDV) with monoclonal antibodies and by cross-neutralization. Brazilian Journal of Medical and Biological Research, v.31, p.1429-1438, 1998.

CANAL, C.W. et al. Detection of antibodies to bovine viral diarrhea virus (BVDV) and characterization of genomes of BVDV from Brazil. Veterinary Microbiology, v.63, p.85-97, 1998.

CARLSSON, U. Border disease in sheep caused by transmission of virus from cattle persistently infected with bovine virus diarrhea virus. Veterinary Record, v.128, p.145-147, 1991.

FLORES, E.F. et al. Clinical, pathological and antigenic aspects of bovine viral diarrhea virus (BVDV) type 2 isolates identified in Brazil. Veterinary Microbiology, v.77, p.175-183, 2000.

JUBB, K.V.F.; HUXTABLE C. R. The Nervous system. In: JUBB, K.V.F., KENNEDY, P.C., PALMER, N. Pathology of domestic animals. 4.ed. San Diego : Academic, 1993. p.289-291.

MONIES, R.J.; SIMPSON V.R. Syndrome in sheep resembling mucosal disease in cattle. Veterinary Record, v.141, p.451, 1997.

NETTLETON, F.P.; ENTRICAN, G. Ruminant pestiviruses. British Veterinary Journal, v.151, p.615642, 1995.

NETTLETON, P.F. et al. Border disease of sheep and goats. Veterinary Research, v.29, p.327-340, 1998.

PATON, D.J. et al. A proposed division of the pestivirus genus using monoclonal-antibodies, supported by cross-neutralization assays and genetic sequencing. Veterinary Research, v.26, p.92109, 1995.

RADOSTITS, O.M. et al. Veterinary medicine. 9.ed. London : Saunders, 2000. 1877p.

RIJN, P.A. et al. Subdivision of the Pestivirus genus based on envelope glycoprotein E2. Virology, v.237, p.337-348, 1997.

TERPSTRA, C.; WENSVOORT, G. Natural infections of pig with bovine viral diarrhea virus associated with signs resembling swine fever. Research in Veterinary Science, v.45, p.137-142, 1988 .

TIJSSEN, P. et al. Immunodominant E2 (gp53) sequences of highly virulent bovine viral diarrhea group II viruses indicate a close resemblance to a subgroup of border disease viruses. Virology, v. 217, p.356-361, 1996.

THOMSON, G.R.; HARKNESS, J.W. Border disease. In: COETZER, J.A.W.; THOMSON, G.R.; TUSTIN, R.C. Infectious diseases of livestock. Oxford : University, 1994. p.651-653.

THÜR, B. et al. Immunohistochemical diagnosis of pestivirus infection associated with bovine and ovine abortion and perinatal death. American Journal of Veterinary Research, v.58, p.13711375, 1997.

THÜR, B. et al. Pestivirus as a causative agent of abortion and perinatal mortality in cattle and sheep in Switzerland. Deutsche Tierärztlichen Wochenschrift, v.105, p.145-148, 1998. 